\title{
KAJIAN PENCAHAYAAN ALAMI PADA RUANG LABORATORIUM FAKULTAS SAINS DAN TEKNOLOGI UIN ALAUDDIN MAKASSAR
}

\author{
Safruddin Juddah*, Muhammad Attar, Moh. Sutrisno \\ Teknik Arsitektur \\ Fakultas Sains dan Teknologi UIN Alauddin Makassar \\ Jl. Sultan Alauddin No. 63, Kabupaten Gowa, Sulawesi Selatan. 92113 \\ *E-mail: safruddin.juddah@uin-alauddin.ac.id
}

\begin{abstract}
Abstrak: UIN Alauddin Makassar sebagai salah satu universitas terbesar di Indonesia berada di garis ekuator, memiliki iklim tropis sehingga memperoleh energi cahaya dari matahari yang cukup melimpah, gratis dan hampir tersedia setiap hari. Meskipun demikian, masih banyak ruang-ruang dalam bangunannya yang masih menggunakan sumber listrik buatan untuk menerangi ruangan, salah satunya gedung D Fakultas Sains dan Teknologi. Hal ini berbanding terbalik dengan desain gedung yang memiliki bukaan dinding pada selubung bangunan dan void di bagian tengah gedung. Penelitian ini bertujuan menganalisis iluminasi ruang laboratorium yang disebabkan oleh perbedaan orientasi bukaan dinding dan luas bukaannya, menganalisis tingkat perubahan iluminasi cahaya alami sepanjang hari, dan mensimulasikan iluminasi yang sesuai dengan standar kebutuhan ruang laboratorium. Laboratorium Fakultas Sains \& Teknologi Universitas Islam Negeri Alauddin Makassar menjadi lokasi pada penelitian ini, terdapat empat ruangan yang dipilih sebagai sampel yaitu: Ruang Laboratorium Zoologi, Laboratorium Optik, Laboratorium Fisika Dasar, dan Laboratorium Mikroprocessor \& Robotik. Penelitian ini memperoleh hasil bahwa terdapat perbedaan iluminasi dan ukuran minimal luas bukaan dinding akibat perbedaan arah orientasi bukaan.
\end{abstract}

Kata Kunci: iluminasi, laboratorium, orientasi dan luas bukaan

\section{PENDAHULUAN}

$\mathrm{M}$ anusia membutuhkan cahaya dalam berbagai kegiatan sehari-hari, kesehatan, dan kenyamanan. Sinar matahari memberikan energi dan inspirasi yang tidak akan habis bagi manusia. Keindahan tidak akan nampak dan dinikmati bila tanpa cahaya. Tanpa cahaya, tidak ada arsitektur (Satwiko, 2008). Penggunaan cahaya matahari dalam proses perancangan bangunan sebagai sumber cahaya alami yang aktif akan memengaruhi kenyamanan penghuni baik secara visual maupun termal. Hal ini juga akan berpengaruh terhadap susunan ruang, bentuk struktur dan penggunaan energi lainnya (Rahim, 2009).

Iluminasi yang cukup dapat meningkatkan produktivitas dan performa, mengurangi mata lelah, serta dapat meningkatkan peluang untuk berhasil. Akan tetapi, pencahayaan alami juga memiliki berbagai kelemahan, di antaranya: intensitas radiasi matahari yang besar, silau, dan distribusi cahaya yang tidak seragam (Lim et al., 2012). 
Sistem pencahayaan dalam bangunan sangat berperan untuk membentuk kesan pada ruang dalam arsitektur yang dalam perencanaannya meliputi berbagai aspek seperti estetika cahaya, ruang, dan manusia sebagai pengguna. Ketidaknyamanan visual, daya penglihatan berkurang atau keduanya diakibatkan oleh cahaya yang kurang atau berlebihan (Rashid, 2005). Beberapa penelitian memperlihatkan bahwa penggunaan pencahayaan alami dalam ruangan belajar mampu membantu peningkatan etos belajar sehingga menjadi salah satu aspek penting dalam desain sekolah atau fasilitas pendidikan yang menggunakan energi berkelanjutan (American Society of Heating, Refrigerating and Air-Conditioning Engineers, 2008).

Iluminasi cahaya yang masuk ke interior bangunan sangat terpengaruh pada perubahan jalur lintasan matahari yang terus bergerak dari timur ke barat serta dari sudut $23.5^{\circ} \mathrm{LU}$ di bulan Juni, kemudian berada pada garis ekuator $\left(0^{\circ}\right)$ di bulan Maret dan September, dan berada pada sudut $23.5^{\circ}$ LS di bulan Desember (Tangoro, 2004). Orientasi bangunan menjadi salah satu aspek yang penting untuk dipertimbangkan oleh arsitek ketika akan memanfaatkan cahaya matahari sebagai sumber cahaya maksimum untuk interior bangunan yang dimulai dari pemilihan lokasi site akan dibangun. Selain itu, pemanfaatan cahaya alami akan menginformasikan kepada pengguna gedung akan kondisi di luar bangunan seperti keadaan cuaca dan perubahan waktu (Phillips \& Gardner, 2012).

Iluminasi yang dipancarakan matahari ke permukaan bumi sangat besar yaitu sebesar 10.000 lux pada kondisi langit berawan hingga lebih 100.000 lux pada kondisi langit cerah. Pemanfaatannya akan dipengaruhi oleh rotasi bumi terhadap matahari serta lokasi ruangan atau gedung tersebut berada. Ruangan dengan sistem pencahayaan alaminya berorientasi timur-barat akan memperoleh dampak yang sangat baik dari rotasi bumi yang berputar dari barat ke arah timur (Irianto, 2006). Selain kondisi langit, faktor lain yang berpengaruh terhadap ketersediaan cahaya dan tingkat penetrasinya cahaya alami adalah orientasi bukaan, lokasi bukaan, ketinggian serta lebar efektif jendela (Boubekri, 2008).

Pada standar nasional yang berlaku, iluminasi ruang laboratorium yang standar adalah sebesar 500 lux (SNI 6197, 2011). Oleh karena itu, berdasarkan standar tersebut maka ditentukan pada penelitian ini untuk iluminasi rata-rata yang diharapkan tercapai minimal sebesar 500 lux. Penelitian ini dilakukan di Kabupaten Gowa Jl. Sultan Alauddin No. 36 yaitu Kampus II UIN Alauddin Makassar yang secara geografis berada pada

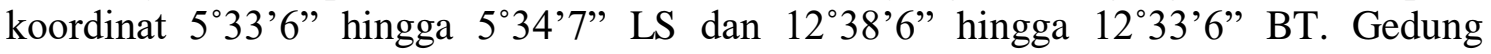
laboratorium Fakultas Sains \& Teknologi yang dipilih terdiri dari empat ruang laboratorium yang mewakili empat arah orientasi bukaan yaitu: Ruang Laboratorium Zoologi (orientasi bukaan timur-barat), Laboratorium Optik (orientasi bukaan selatanutara), Laboratorium Fisika Dasar (orientasi bukaan barat-timur), dan Laboratorium Mikroprocessor \& Robotik (orientasi bukaan utara-selatan).

Ruang laboratorium yang menjadi objek penelitian ini berada pada lantai 2 (dua). Gedung ini memiliki void pada tengah gedung untuk meneruskan cahaya dan penghawaan alami ruang-ruang laboratorium seluas $705,7 \mathrm{~m}^{2}$ atau $23,87 \%$ dari luas lantai tipikal gedung. Ruang-ruang pada gedung ini bisa dilihat pada Gambar 2. 


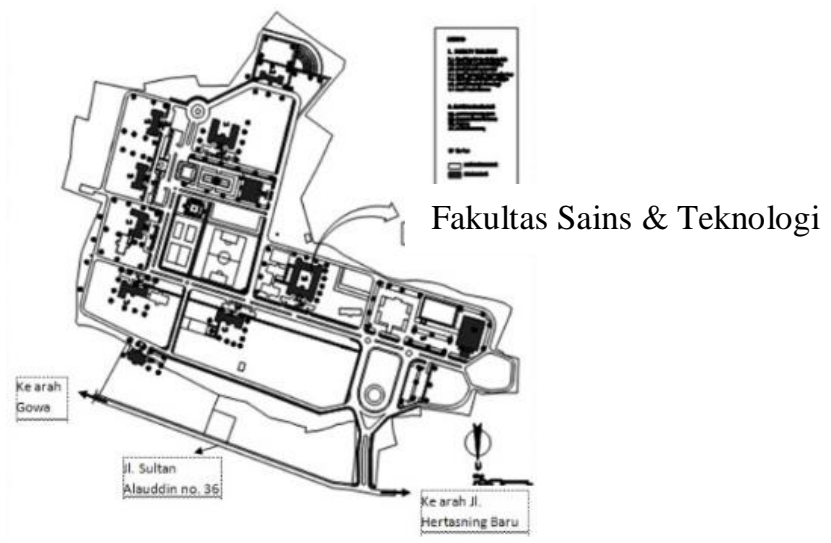

Gambar 1. Master plan Kampus II UIN Alauddin Makassar

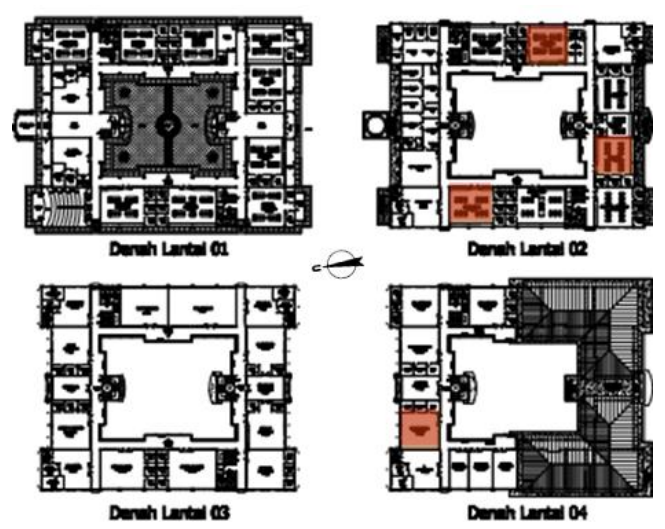

Gambar 2. Denah lantai 01-04 gedung laboratorium Fakultas Sains \& Teknologi UIN Alauddin Makassar

\section{METODE PENELITIAN}

Penelitian menggunakan metode kuantitatif teoritik eksperimental dengan langkah awal berupa pengukuran data eksisting di lapangan selanjutnya menginput data tersebut ke dalam tabel data untuk menghitung besarnya nilai iluminansi rata-rata pada titik ukur melalui aplikasi Microsoft Excel.

Pada proses pengumpulan data dilakukan melalui observasi lapangan dengan menggunakan lux meter pada titik ukur yang berjarak $\pm 75 \mathrm{~cm}$ dari lantai pada tiap 3 (tiga) meter (luas ruangan laboratorium yang ada antara 10-100 $\mathrm{m}^{2}$ (SNI 7062, 2004). Letak titik ukur pada ruang laboratorium ini dapat dilihat pada Gambar 3.
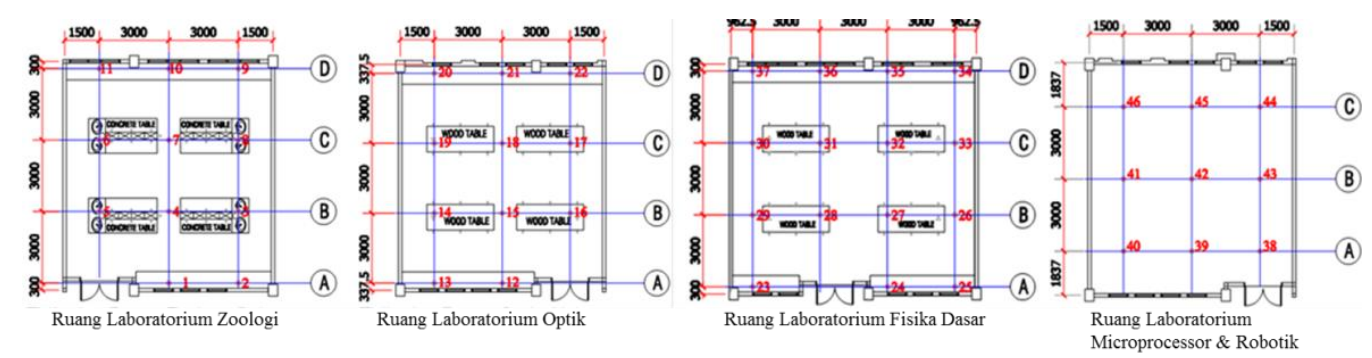

Gambar 3. Perletakan titik ukur ruang laboratorium 
Metode analisis data yang digunakan adalah analisis deskriptif dengan menggunakan rumus pada persamaan 1 .
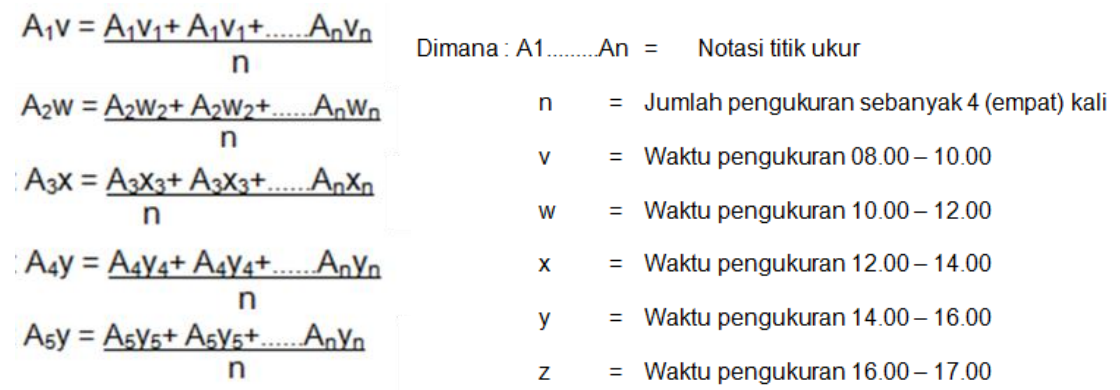

Hasil tersebut selanjutnya dianalisa dengan menggunakan regresi polynomial untuk mendapatkan tingkat korelasi pada persamaan 2.

$$
\begin{aligned}
\mathrm{Y} & =\mathrm{a} \mathrm{X}^{2}+\mathrm{bX}+\mathrm{C} \\
\text { Dimana: } \mathrm{y} & =\text { Variabel Bebas } \\
\mathrm{X} & =\text { Variabel tak bebas } \\
\mathrm{a} \text { dan } \mathrm{b} & =\text { Kostanta }
\end{aligned}
$$

Langkah selanjutnya adalah melakukan simulasi melalui penggunaan aplikasi komputer Autodesk Ecotect 2011 untuk mencari alternatif solusi terhadap perbaikan intensitas pencahayaan pada ruang-ruang laboratorium Fakultas Sains \& Teknologi. Hasil simulasi dapat menjadi rekomendasi untuk perbaikan kualitas pencahaayan alami sebagai bagian dari kenyamanan visual pada gedung tersebut.

\section{HASIL DAN PEMBAHASAN}

Hasil perhitungan dan simulasi kondisi eksisting laboratorium menunjukkan bahwa berdasarkan orientasi dan luas bukaan yang ada pada ruang-ruang laboratorium tersebut belum memenuhi standar iluminasi sebesar 500 lux. Pengukuran data iluminasi eksisting pada eksterior ruang di atap gedung lantai 03 dan pada interior laboratorium dilaksanakan pada waktu yang bersamaan berdasarkan berbagai kondisi langit yang tersedia. Pengambilan data lapangan dilaksanakan selama 4 (empat) hari pada waktu pagi hingga sore hari dengan rentang waktu per 2 (dua) jam yaitu pukul 08.00-10.00, 10.00$12.00,12.00-14.00,14.00-16.00$ dan 16.00-17.00. Iluminasi rata-rata ruang laboratorium dapat dilihat pada Tabel 1.

Tabel 1. Iluminasi rata-rata hasil pengukuran pada luar ruangan (top floor)

\begin{tabular}{ccc}
\hline No. & Periode Pengukuran (Jam) & Rata-rata Nilai Iluminasi (Lux) \\
\hline 1 & $08.00-10.00$ & 18.091 \\
\hline 2 & $10.00-12.00$ & 49.538 \\
\hline 3 & $12.00-14.00$ & 54.119 \\
\hline 4 & $14.00-16.00$ & 24.951 \\
\hline 5 & $16.00-17.00$ & 18.911 \\
\hline
\end{tabular}

Pada periode pengukuran jam 08.00-10.00 s/d 12.00-14.00 terjadi peningkatan nilai rata-rata iluminasi yang disebabkan oleh kenaikan intensitas cahaya luar pada pagi hari hingga siang hari, dan terjadi penurunan pada jam 12.00-14.00 s/d 16.00-17.00. 


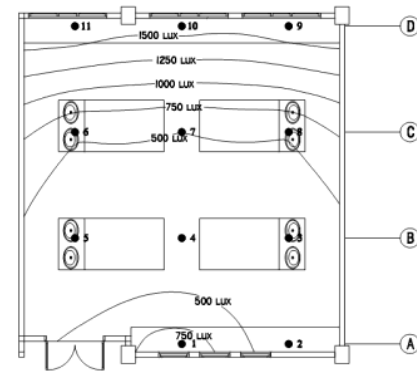

Jam 08.00-10.00

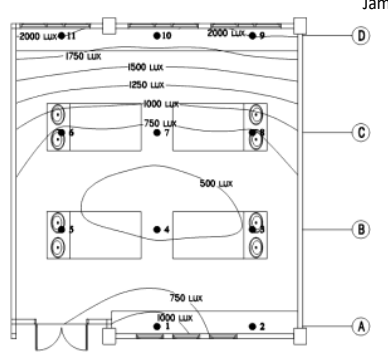

Jam 14.00-16.00

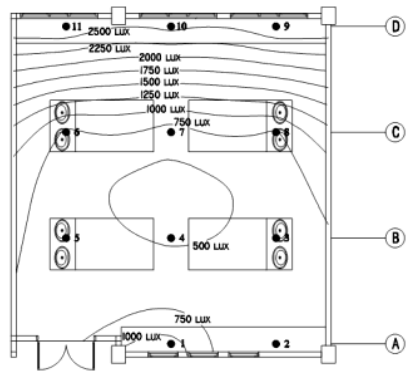

Jam 10.00-12.00

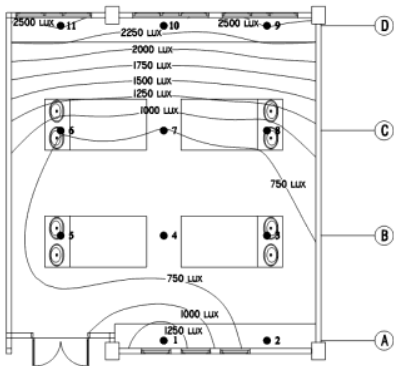

$\operatorname{Jam} 12.00-14.00$

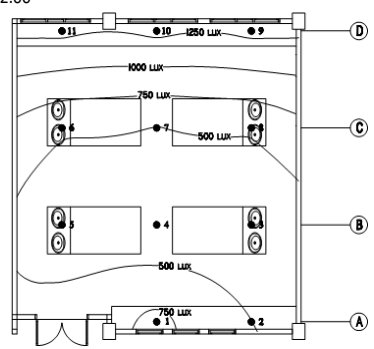

Jam 16.00-17.00

Gambar 4. Grafik kontur iluminasi ruang Laboratorium Zoologi hasil pengukuran
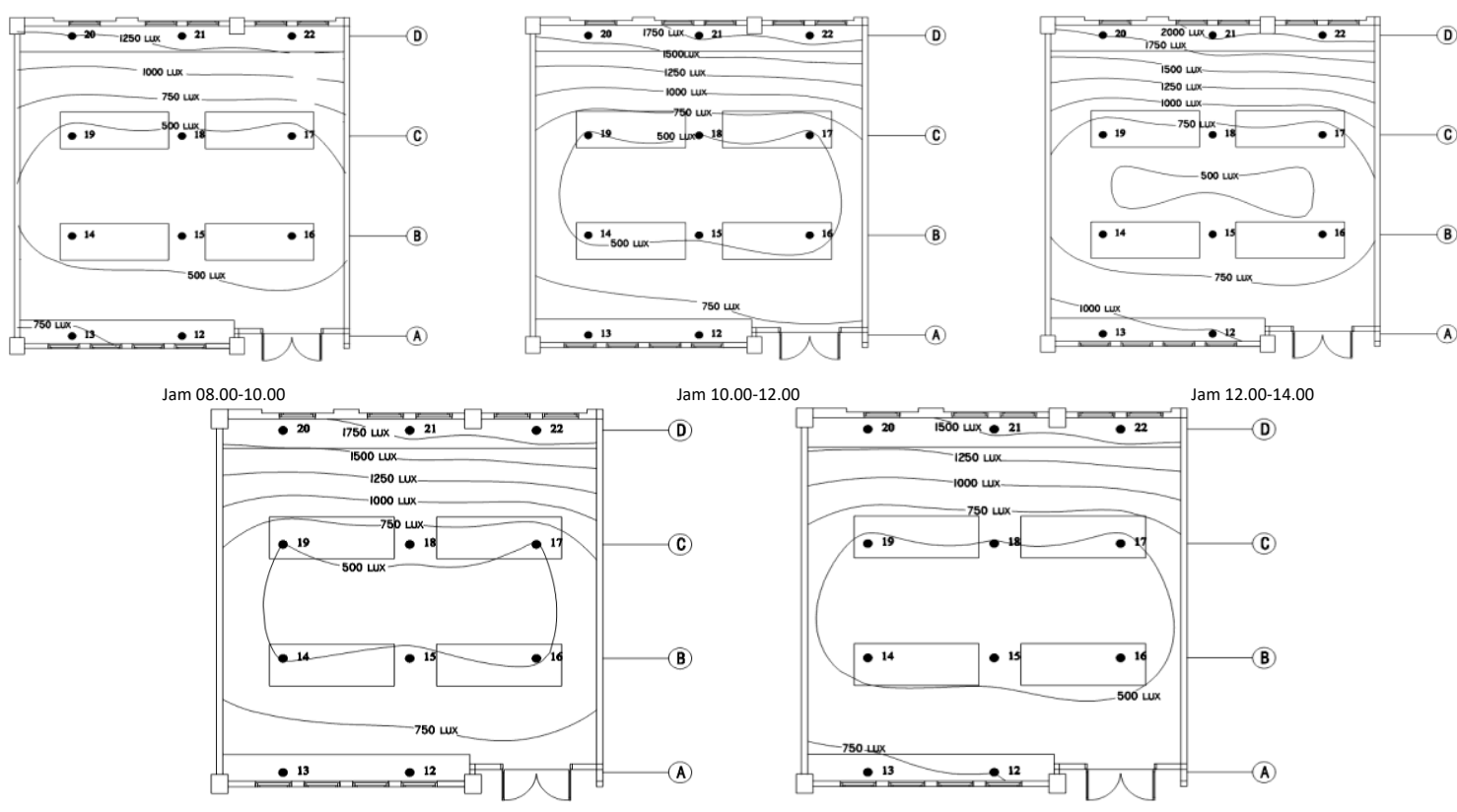

Jam 14.00-16.00

10.00-12.00

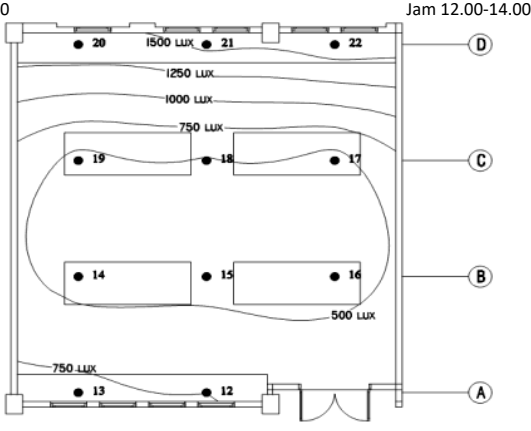

Jam 16.00-17.00

Gambar 5. Grafik kontur iluminasi ruang Laboratorium Optik hasil pengukuran

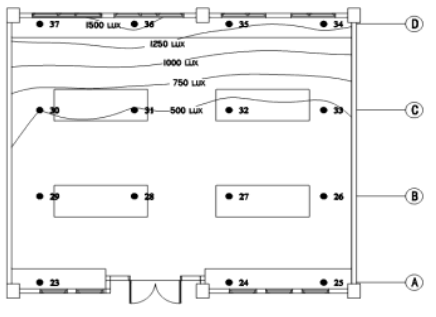

Jam 08.00-10.00

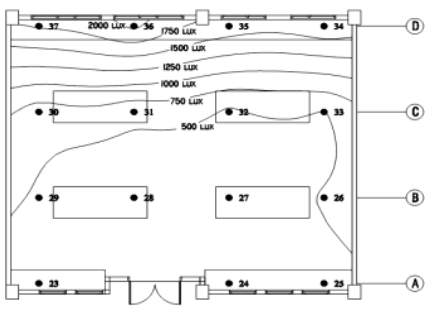

Jam 10.00-12.00

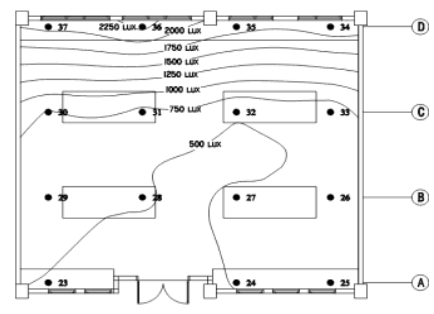

Jam 12.00-14.00 


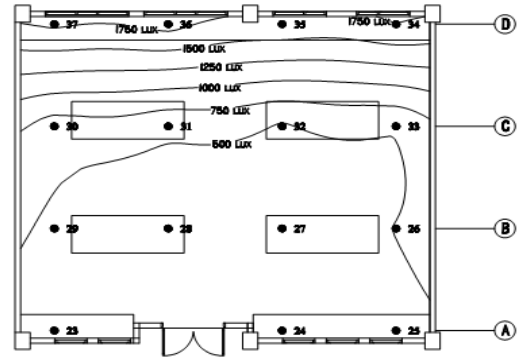

Jam 14.00-16.00

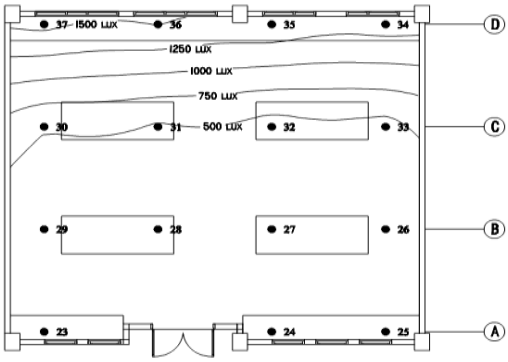

Jam 16.00-17.00

Gambar 6. Grafik kontur iluminasi ruang Laboratorium Fisika Dasar hasil pengukuran
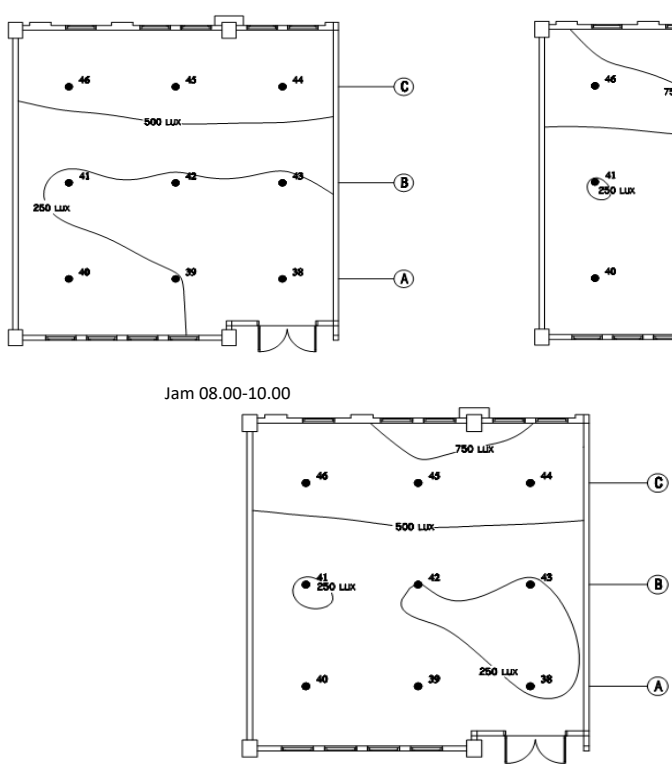

Jam 14.00-16.00

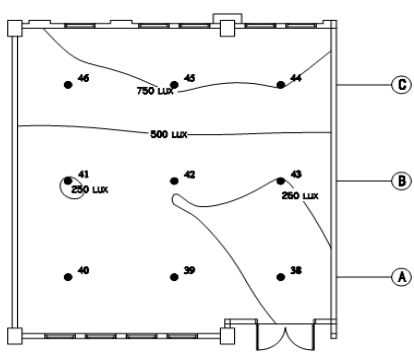

Jam 10.00-12.00

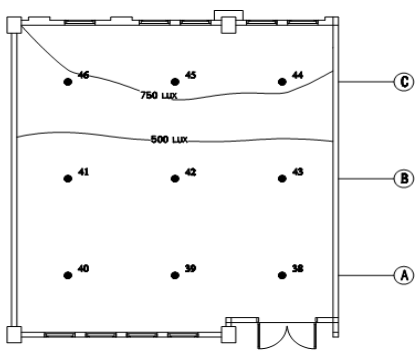

Jam $12.00-14.00$

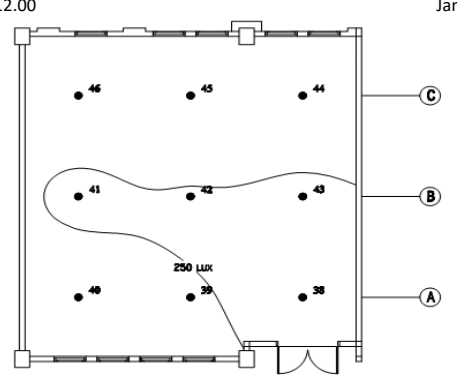

Jam 16.00-17.00

Gambar 7. Grafik kontur iluminasi ruang Laboratorium Mikroprocessor \& Robotik hasil pengukuran

Pengukuran dan penggambaran grafik kontur iluminasi menggambarkan bahwa beberapa area pengukuran tidak memenuhi standar iluminasi ruang laboratorium. Ruang Laboratorium Zoologi pada titik ukur B tidak memenuhi standar sementara pada titik ukur A, C, dan D memenuhi standar iluminasi. Ruang Laboratorium Optik pada titik ukur $\mathrm{B}$ dan $\mathrm{C}$ tidak memenuhi standar pencahayaan sementara titik ukur A dan D memenuhi. Ruang Laboratorium Fisika Dasar pada titik ukur A dan B tidak memenuhi standar sementara titik ukur C dan D memenuhi standar. Ruang Laboratorium Mikroprocessor \& Robotik daerah yang tidak memenuhi standar iluminasi adalah titik ukur A dan B sementara titik ukur $\mathrm{C}$ memenuhi standar iluminasi. Hasil Pengukuran tersebut dapat dilihat pada Gambar 4-7.

Letak bukaan dinding sebagai jalur masuknya cahaya alami yang tegak lurus terhadap arah sumber cahaya menyebabkan Ruang Laboratorium Zoologi dan Fisika Dasar memiliki perubahan tingkat iluminasi yang signifikan antara titik ukur C dan D. Sementara iluminasi yang cenderung merata atau stabil terlihat pada Ruang Laboratorium Optik dan Mikroprocessor \& Robotik yang dipengaruhi oleh cahaya yang diterima ruangan adalah cahaya refleksi/pantulan karena arah bukaan yang searah dengan lintasan cahaya matahari. 

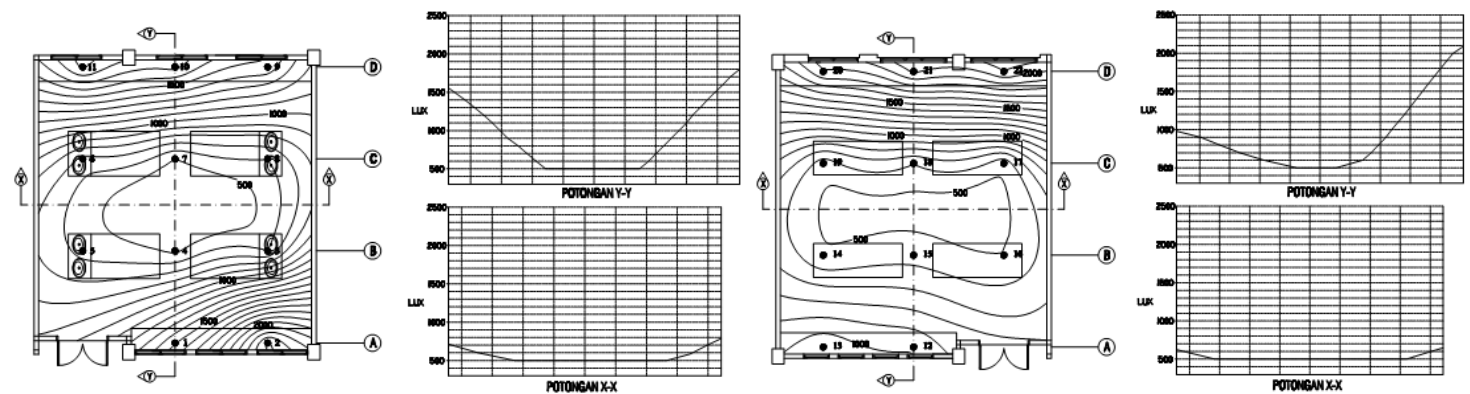

Gambar 8. Garis kontur dan potongan iluminasi hasil simulasi ruang Laboratorium Zoologi dan Optik
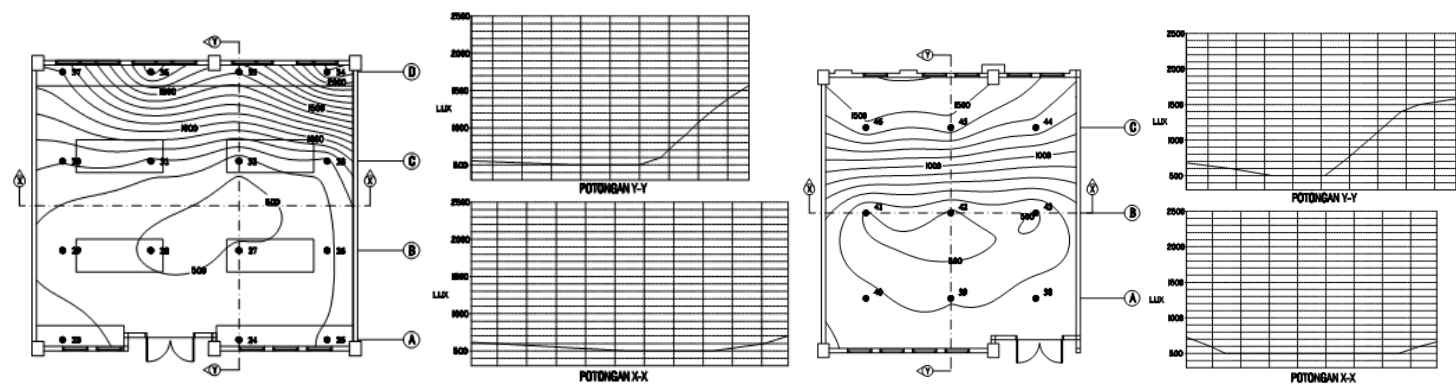

Gambar 9. Garis kontur dan potongan iluminasi hasil simulasi ruang Laboratorium Fisika Dasar dan Mikroprocessor \& Robotik

Hasil tersebut di atas menjelaskan bila orientasi dan luas bukaan sangat berpengaruh terhadap besaran iluminasi alami dalam ruang laboratorium. Hal ini menjadi dasar pertimbangan untuk merubah besar bukaan dinding pada laboratorium yang ada, termasuk dalam membuat ruangan yang serupa.

Pengujian melalui simulasi Autodesk Ecotect 2011 menjadi pembanding terhadap hasil pengukuran lapangan. Perbandingan tersebut dibuatkan nilai rata-rata deviasi yang menunjukkan hasil simulasi lebih besar dari data lapangan. Titik temu antara hasil pengukuran dan hasil simulasi diperoleh pada pukul 08.00-10.00 dengan nilai simulasi 10.135 lux, pukul 10.00-12.00 dengan nilai simulasi 12.500 lux, pukul 12.00-14.00 dengan nilai simulasi 15.000 lux, pukul 14.00-16.00 dengan nilai simulasi 13.500 lux, dan pukul 16.00-17.00 dengan nilai simulasi 11.000 lux.

Hasil uji simulasi menunjukkan bahwa untuk memenuhi standar iluminasi maka luas bukaan pada ruang Laboratorium Zoologi minimum sebesar $11 \%$ dengan persentase ruang yang memenuhi nilai 500 lux sebanyak 87,73\%, ruang Laboratorium Optik minimum sebesar $13 \%$ dengan persentase ruang yang memenuhi nilai 500 lux sebanyak 87,14\%, ruang Laboratorium Fisika Dasar minimum sebesar 13\% dengan persentase ruang yang memenuhi nilai 500 lux sebanyak 90,93\%, dan ruang Mikroprocessor \& Robotik minimum $18 \%$ dengan persentase ruang yang memenuhi nilai 500 lux sebanyak 93,58\%. Hasil simulasi ditunjukkan pada Gambar 10. 


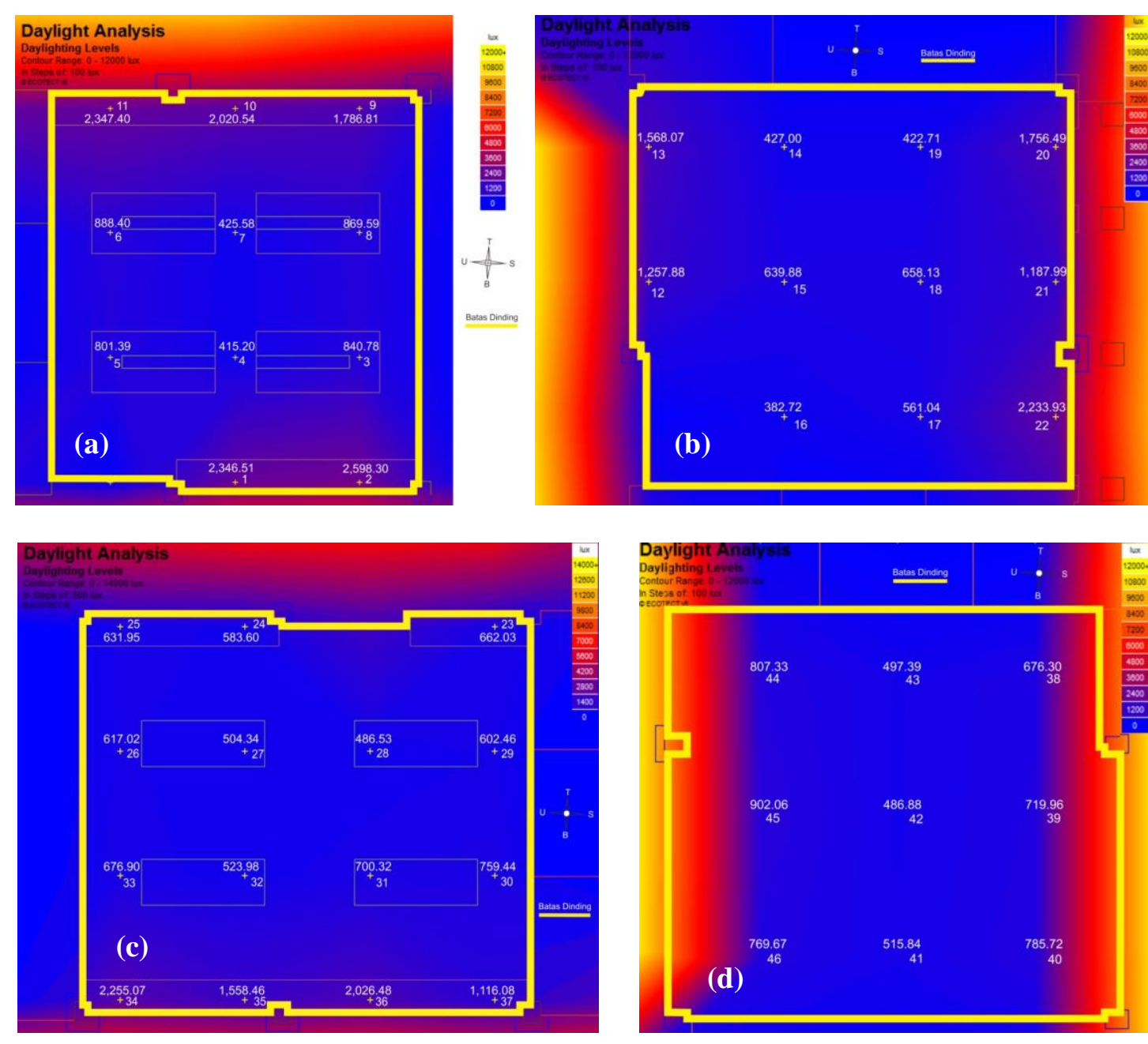

Gambar 10. Garis kontur iluminasi hasil simulasi dengan ecotect pada laboratorium; a. Ruang Zoologi, b. Ruang Optik, c. Ruang Fisika Dasar, d. Ruang Mikroprocessor \& Robotik

Hasil simulasi dibuatkan perbandingan luas dinding dan luas bukaan atau Window to Wall Ratio (WWR) kondisi exixting dan hasil simulasi. Simulasi menggambarkan bahwa WWR yang dibutuhkan untuk ruang Laboratorium Zoologi hanya sebesar 30,82\% yang sebelumnya sebesar $33,23 \%$. ruang Laboratorium Optik dibuat menjadi sebesar $36,15 \%$ dari sebelumnya sebesar 23,83\%. ruang Laboratorium Fisika Dasar dibuat menjadi sebesar 35,07\% dari sebelumnya sebesar 32,73\%. Ruang Laboratorium Mikroprocessor dan Robotik dibuat menjadi lebih besar yaitu 50,04\% dari sebelumnya sebesar 25,01. Ratio perbandingan Window to Wall Ratio (WWR) untuk ruang laboratorium Fakultas Sains \& Teknologi UIN Alauddin Makassar berdasarkan hasil simulasi dapat dilihat pada Tabel 2 dan Tabel 3. 
Tabel 2. Window to Wall Ratio (WWR) pengukuran lapangan pada ruang laboratorium

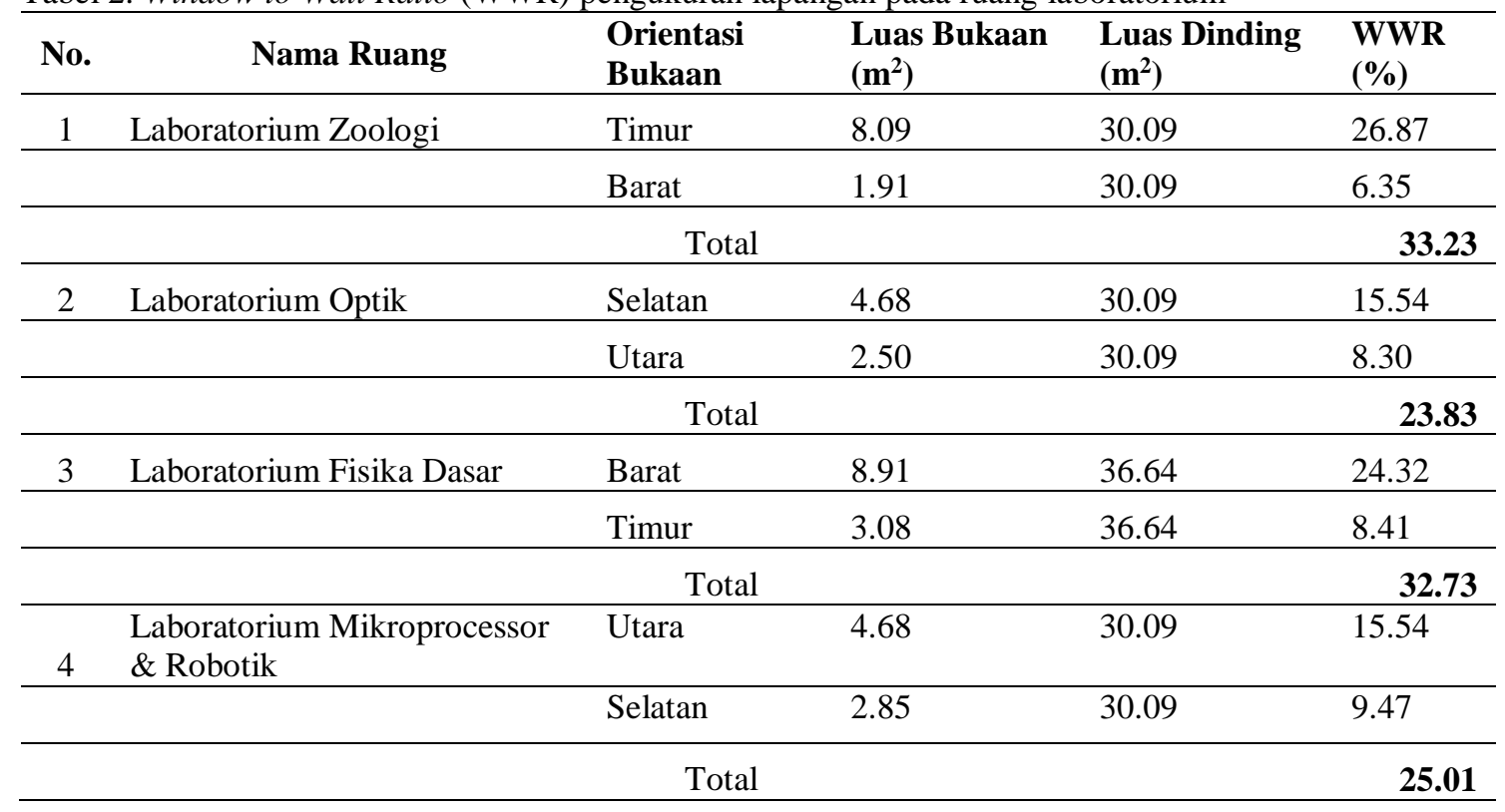

Tabel 3. Window to Wall Ratio (WWR) pada ruang laboratorium hasil simulasi

\begin{tabular}{|c|c|c|c|c|c|}
\hline No. & Nama Ruang & $\begin{array}{l}\text { Orientasi } \\
\text { Bukaan }\end{array}$ & $\begin{array}{l}\text { Luas Bukaan } \\
\text { (m2) }\end{array}$ & $\begin{array}{l}\text { Luas Dinding } \\
(\mathrm{m} 2)\end{array}$ & $\begin{array}{l}\text { WWR } \\
(\%)\end{array}$ \\
\hline \multirow[t]{3}{*}{1} & Laboratorium Zoologi & Timur & 5.61 & 30.09 & 18.65 \\
\hline & & Barat & 3.66 & 30.09 & 12.18 \\
\hline & & & & Total & 30.82 \\
\hline \multirow[t]{3}{*}{2} & Laboratorium Optik & Selatan & 7.26 & 30.09 & 24.13 \\
\hline & & Utara & 3.62 & 30.09 & 12.02 \\
\hline & & & & Total & 36.15 \\
\hline \multirow[t]{3}{*}{3} & Laboratorium Fisika Dasar & Barat & 7.48 & 36.64 & 20.42 \\
\hline & & Timur & 5.37 & 36.64 & 14.65 \\
\hline & & & & Total & 35.07 \\
\hline \multirow[t]{3}{*}{4} & Laboratorium Mikroprocessor & Utara & 8.46 & 30.09 & 28.12 \\
\hline & & Selatan & 6.60 & 30.09 & 21.92 \\
\hline & & & & Total & 50.04 \\
\hline
\end{tabular}

\section{KESIMPULAN}

Orientasi dan luas bukaan sangat berpengaruh terhadap besaran iluminasi alami dalam ruang laboratorium sehingga harus dipertimbangkan dengan baik dalam mendesain ruangan yang serupa. Hasil penelitian menjelaskan bahwa ruang yang berorientasi timur dan barat dengan bukaan dinding pada sisi sebelah selatan dan utara memerlukan luas bukaan sebesar 13\%-18\%. Sementara ruang yang berorientasi utara dan selatan dengan bukaan dinding pada sisi sebelah barat dan timur memerlukan luas bukaan lebih kecil yaitu sebesar 11\%-18\%.

Iluminasi mengalami kenaikan dan penurunan di titik ukur setiap hari. Kenaikan terjadi pada pukul $08.00-10.00$ s/d 12.00-14.00 mencapai $86 \%$ dan turun pada pukul $12.00-14.00 \mathrm{~s} / \mathrm{d}$ 16.00-17.00 sebesar $-42 \%$. Iluminasi pada ruang Laboratorium Zoologi sudah terpenuhi melalui bukaan eksisting seluas 12\% dengan minimum luas yang dibutuhkan sebesar 11\%. Sedangkan pada ruang Laboratorium Optik, Fisika Dasar, dan 
Mikroprocessor \& Robotik belum memenuhi standar sehingga harus dilakukan perubahan besar luas bukaan dinding. Pada ruang Laboratorium Optik dibutuhkan bukaan minimum seluas $13 \%$ sementara eksisting hanya 9\%. Pada ruang Laboratorium Fisika Dasar dibutuhkan luas bukaan minimum seluas $13 \%$ sementara eksistingnya hanya sebesar 12\%. Pada Ruang Laboratorium Mikroprocessor \& Robotik dibutuhkan luas bukaan dua kali lipat dengan minimum seluas $18 \%$ sementara eksisting hanya seluas $9 \%$. Berdasarkan hasil tersebut maka perlu diadakan perubahan berupa pengurangan dan penambahan jumlah bukaan dinding untuk ruang laboratorium di Fakultas Sains \& Teknologi Universitas Islam Negeri Alauddin Makassar agar tercapai iluminasi yang standar pada ruang laboratorium sebesar 500 lux.

\section{DAFTAR PUSTAKA}

American Society of Heating, Refrigerating and Air-Conditioning Engineers, I. (2008). Advanced energy design guide for K-12 school buildings: Achieving 30\% energy savings toward a net zero energy building. United State: American Society of Heating, Refrigerating and Air-Conditioning Engineers.

Boubekri, M. (2008). Daylighting, architecture and health: Building design strategies. In Daylighting, architecture and health. Oxford: Architectural Press.

Irianto, C. G. (2006). Studi optimasi sistem pencahayaan ruang kuliah dengan memanfaatkan cahaya alam. JETri, 5(2), 1-20.

Lim, Y. W., Kandar, M. Z., Ahmad, M. H., Ossen, D. R., \& Abdullah, A. M. (2012). Building façade design for daylighting quality in typical government office building. Building and Environment, 57, 194, 204. Doi. 10.1016/j.buildenv.2012.04.015.

Phillips, D., \& Gardner, C. (2012). Daylighting: Natural light in architecture. Britania Raya: Routledge.

Rahim, R. (2009). Teori dan aplikasi distribusi luminansi langit di Indonesia. Makassar: Jurusan Arsitektur Fakultas Teknik Universitas Hasanuddin.

Rashid, M. S. B. (2005). Physiological reaction to light: the understanding of lighting design truoght health and visual safety. Bandung: Jurusan Arsitektur Institut Teknologi Bandung.

Satwiko, P. (2008). Fisika bangunan. Yogyakarta: ANDI.

SNI 6197, 2011. (2011). Konservasi energi pada sistem pencahayaan. Standar Nasional Indonesia.

SNI 7062, 2004. (2004). Pengukuran intensitas penerangan di tempat kerja. Standar Nasional Indonesia. Tangoro, D. (2004). Utilitas bangunan. Jakarta: Universitas Indonesia Press. 